J. Environ. Sci.

Institute of Environmental Studies and Research - Ain Shams University

\title{
BIOLOGICAL CONTROL OF FUSARIUM WILT DISEASE IN SWEET BASIL PLANT
}

\begin{abstract}
Sabah A. Mohamed ${ }^{(1)}$;Nazmy A. Abd EL-Ghany ${ }^{(2)}$; Mohamed G. A. Nada ${ }^{(3)}$ and Mohammed H. M. Ramadan ${ }^{(4)}$

1) Agriculture Research Center, Giza 2) Vice President of Ain Shams University 3) Medicine and Aromatic Plant Diseases Department, Plant Pathology Research Institute, Agriculture Research Center, Giza 4) Medicine and Aromatic Plant, Faculty of Agric, Ain Shams University.
\end{abstract}

\begin{abstract}
Ocimum basilicum L. (Sweet basil) infected with Fusarium oxysporum was studied from three Governorates (Assuit, Beni-Suif and Fayoum); the highest infection of the basil presented in Beni-Suif Governorate. There are four treatment for control of basil wilt disease, fungicide (Topsin M (1.5 and $3 \mathrm{mg} / \mathrm{L}$ ), bioagent (Bioark (2.5 and $5 \mathrm{mg} / \mathrm{L}$ ), silicon (potassium silicate $2 \& 4$ $\mathrm{mg} / \mathrm{L}$ ) and nanoparticles (Lemon grass $8 \mathrm{ml} / \mathrm{L} \&$ Citronella $8 \mathrm{ml} / \mathrm{L}$ ). Topsin M $(3 \mathrm{mg} / \mathrm{L})$ had the highest significant in increasing of Ocimum length infected with Fusarium in two seasons (2nd season $(39.75 \mathrm{~cm}$ than $1 \mathrm{st}$ season $39.00 \mathrm{~cm}$ ), where the nano Citronella $8 \mathrm{ml} / \mathrm{L}$ gave the lowest efficiency on the plant length in two seasons $(34.23 \& 34.82 \mathrm{~cm})$ for $1 \mathrm{st}$ and 2 nd seasons. Bioagent (Bioark 5mg/L) considered the most significant treatment in increasing the branches fresh weight $(40.53 \& 41.32 \mathrm{mg})$ for $1 \mathrm{st}$ and $2 \mathrm{nd}$ seasons, while the highest effect of bioagent for branches dry weight (12.65 $\& 13.20 \mathrm{gm}$ ) for 1st and 2nd seasons. Root length, root fresh weight and root dry weight; bioagent (Bioark $5 \mathrm{mg} / \mathrm{L}$ ) gave the highest effect on root length $(12.43 \& 12.98 \mathrm{~cm})$ root fresh weight $(15.48 \& 16.01 \mathrm{mg})$ and root dry weight $(6.68 \& 6.94 \mathrm{mg})$ for first and second season respectively. Finally, essential oil content in Ocimum tissues infected with Fusarium was highest using Bioark 5 $\mathrm{mg} / \mathrm{L}$ treatment into two seasons $(0.07 \mathrm{mg})$ for first and second seasons.

Keywords: Ocimum basilicum, Fusarium oxysporum, Topsin M, Bioark, potassium silicate, Lemon grass, Citronella
\end{abstract}




\section{INTRODUCTION}

Ocimum basilicum, popular known as Basil or Sweet Basil, is a common herb that belongs to Lamiaceae family. Studies have shown many pharmacological effects in several diseases, with potent antioxidant, antiaging, anticancer, antiviral, and antimicrobial properties (Sakr and AlAmoudi, 2012). Studies have reported that rosmarinic acid (RA) is the most biologically active compound present in Basil related to this activities (Javanmardi et al., 2002; Lee and Scagel, 2009; Shiga et al., 2009).

Ocimum species is cultivated for medicinal purposes, and for religious belief. It has long been documented as a diverse and rich source of essential oils. At the same time, it is used in cooking for its flavor and fragrance, so the fresh or dried leaves add to many foods, such as rice, pasta, and salads (Mabey et al., 1988).

Fusarium wilt is a production constraint in basil and its occurrence is reported from different parts of the world. The disease is caused by Fusarium oxysporum. It is one among the 120 host-species, individual strains (formae species) of the wilt pathogen, Fusarium oxysporum (Fox). During 2000's, a new-wilting disease has impaired $20-40 \%$ of yields of basil (Ocimum basilicum L.) in Taiwan. Wilt and crown rot of sweet basil (Ocimum basilicum), caused by Fusarium oxysporum f. sp. basilici, represents a major problem on this crop. Infected plants with Fusarium showed stunting root/stem rot, defoliation, dieback, vascular discoloration and wilting (AlHatmi et al., 2014).

To effectively manage basil downy mildew while reducing the potential for fungicide resistance development, it is important for conventional basil 
growers to (i) initiate a regular fungicide maintenance program prior to the arrival of the pathogen, (ii) limit the number of applications of high-risk fungicides applied during the production season, and (iii) rotate fungicides with different modes-of-action as indicated by their Fungicide Resistance Action Committee (FRAC group) (Gilardi et al., 2012; Homa et al., 2014).

Biocontrol is the most promising strategy due to presenting advantages related to safety, longevity, environmental conservation and low costeffectiveness with a high return (Wang et al., 2013). Applying bioagent after secondary solid fermentation from organic material and biocontrol agent has been reported to be a timely method for controlling many soil borne diseases (Zhao et al., 2014; Wang et al., 2013).

The combination of white rot infection with silicon nutrition in the form of PS (potassium silicate) via the nutrient solution can improve the impact of disease infection on membrane leakage and lipid peroxidation. The addition of PS can mediated a reduction in lipid peroxidation that is attributed to its regulation of antioxidant activity in plants (Lamb and Dixon, 1997).

The aim of this investigation is studying several tools to control wilt disease of sweet basil by Fusarium in Egypt based on different ways (fungicide (Topsin), bioagent (Bioark), silicon (potassium silicate) and nanoparticles (Lemon grass and Citronella)) and the efficiency of these control on plant growth parameters 


\section{MATERIALS AND METHODS}

The sweet basil infection with Fusarium wilt disease were studied in three governorates (Assuit, Beni-Suif and Fayoum) in two seasons (2014/2015 and 2015/2016) and the percentage of infection were recorded.

\section{Isolation and identification of the associated fungi to infected plant and}

their frequencies (\%): Basil showing wilt symptoms seedlings was collected from the studied governorates in addition to the healthy seedlings and sterilized with sodium hypochlorite (1\%) for $3 \mathrm{~min}$. and left to dry for $6 \mathrm{hrs}$. and transferred to PDA plates and incubated at $25 \pm 2^{\circ} \mathrm{C}$ for 7 days. The growing fungi were purified and identified by means of comparison with the description sheets of Commonwealth Mycological Institute, Kew, Surrey, England (CMI), Danish Government Institute of Seed Pathology (DGISP) publications as well as publications of Ellis, 1971; Moubasher, 1977; Nelson et al. (1983); Booth, 1985; Burrges et. al., 1988; and Singh et al., 1991 according to their morphological and cultural characteristics. Percentage of frequency per each fungus was also determined as follows:

$$
\% \text { frequency }=\frac{\text { No.of isolates per each fungus }}{\text { Total no.of the isolated fungi }} \times 100
$$

Control Studies: Four control agents were used fungicide (one fungicide (Topsin M) with two concentration (1.5 and $3 \mathrm{mg} / \mathrm{L})$ ), bioagent (bioark with two concentrations $2.5 \mathrm{mg} / \mathrm{L}$ and $5 \mathrm{mg} / \mathrm{L}$ ), silicon (potassium silicate with two concentrations $2 \mathrm{mg} / \mathrm{L}$ and $4 \mathrm{mg} / \mathrm{L}$ ), finally nano control using lemon grass $(8 \mathrm{ml} / \mathrm{L})$ and Citronella $(8 \mathrm{ml} / \mathrm{L})$. Different controls were used for Fusarium wilt basil disease. The healthy seedlings and seedlings infected with Fusarium were treated with two concentrations of Topsin $M$ and transplants in field plots $(3 \times 4 \mathrm{~m})$ for two seasons. After 60 and 120 days from 
transplanting, plant growth parameters (plant height $(\mathrm{cm})$, branches fresh and dry weights, root length, root fresh and dry weights, in addition to essential oil of basil leaves produced from each treatment was extracted with steam distillation and determined according to Guenther (1961).

Infection percentage of wilt disease was determined as follows:

$$
\text { Infection percentage }=\frac{\text { Wilted plants }}{\text { Total Plants }} X 100
$$

Statistical analysis: The data obtained were statistically analyzed and computed giving L.S.D. according to Sendecor and Cochran (1989).

\section{RESULTS}

\section{Identification of the associated fungi to infected basil and their frequency}

(\%): There are 158 isolates from seven isolated fungi. The mean frequency percentages of the isolated fungi were $100 \%$. The highest frequency percentage was recorded for Fusarium oxysporum (81\%) with 18 isolates, where the lowest percentage of frequency was reported for Pythium sp. (0.60 $\%)$ with one isolate as shown in Table (1).

Table (1): Mean value of number of isolates of associated fungi to infected basil and their frequency $(\%)$.

\begin{tabular}{|c|c|c|}
\hline Fungi & No. of isolates & Frequency \% \\
\hline \hline Btryodiplodia theobromae & 2 & 1.30 \\
\hline Fusarium oxysporum & 128 & 81.00 \\
\hline Fusarium semitectum & 4 & 2.50 \\
\hline Fusarium solani & 7 & 4.40 \\
\hline Macrophmina phaseolina & 3 & 2.00 \\
\hline Pythium sp. & 1 & 0.60 \\
\hline Rhizooctonia solani & 13 & 8.20 \\
\hline LSD 0.05 & 1.4879 & 1.4879 \\
\hline
\end{tabular}


Percentage of infection of basil in the study Governorates: The infection percentage of downy mildew disease in basil infected with Fusarium in three Governorates under study was shown in Table (2). Highest mean value of percentage of infection of Ocimum basilicum (basil) with Fusarium oxysporum was found in second season $(31.8 \%)$. The highest percentage of infection was presented in Beni-Suif Governorate in the two seasons $(31.6 \%$ for first season and $38.4 \%$ for the second season)

Table (2): Infection percentage of Ocimum infected with Fusarium through two seasons in three Governorates.

\begin{tabular}{|c|c|c|}
\hline \multirow{2}{*}{ Governorates } & \multicolumn{2}{|c|}{ Infection \% } \\
\cline { 2 - 3 } & $\mathbf{2 0 1 4 / 2 0 1 5}$ season & $\mathbf{2 0 1 5 / 2 0 1 6}$ season \\
\hline \hline Assuit & 24.40 & 29.20 \\
\hline Beni-Sueif & 31.60 & 38.40 \\
\hline Fayoum & 20.60 & 27.80 \\
\hline LSD 0.05 & 3.9309 & 5.0561 \\
\hline
\end{tabular}

Effect of different treatments on plant height (cm): Table (3) showed that fungicide control using Topsin $\mathrm{M}(3 \mathrm{mg} / \mathrm{L})$ had the highest significant in plant length increase in two seasons, it recorded $38.58 \mathrm{~cm}$ and $39.41 \mathrm{~cm}$ length of plant after 60 days and 120 days respectively for the first season compared to the compared to the control infected with fungus (28.20 and 0.00 respectively). For second season, Also Topsin M (3mg/L) gave the highest effect in increasing of plant length with value $39.29 \mathrm{~cm}$ and $40.20 \mathrm{~cm}$ after 60 and 120 days respectively. The lowest effect in plant length was found by using was found by using nano control Citronella $8 \mathrm{ml} / \mathrm{L}$ in two seasons with mean value $34.23 \mathrm{~cm}$ for first season and $34.82 \mathrm{~cm}$ for second season compared to control infected with 
J. Environ. Sci.

Institute of Environmental Studies and Research - Ain Shams University

Table (3): Effect of treatments on plant height $(\mathrm{cm})$ of Ocimum (sweet basil) infected with Fusarium through first and second seasons.

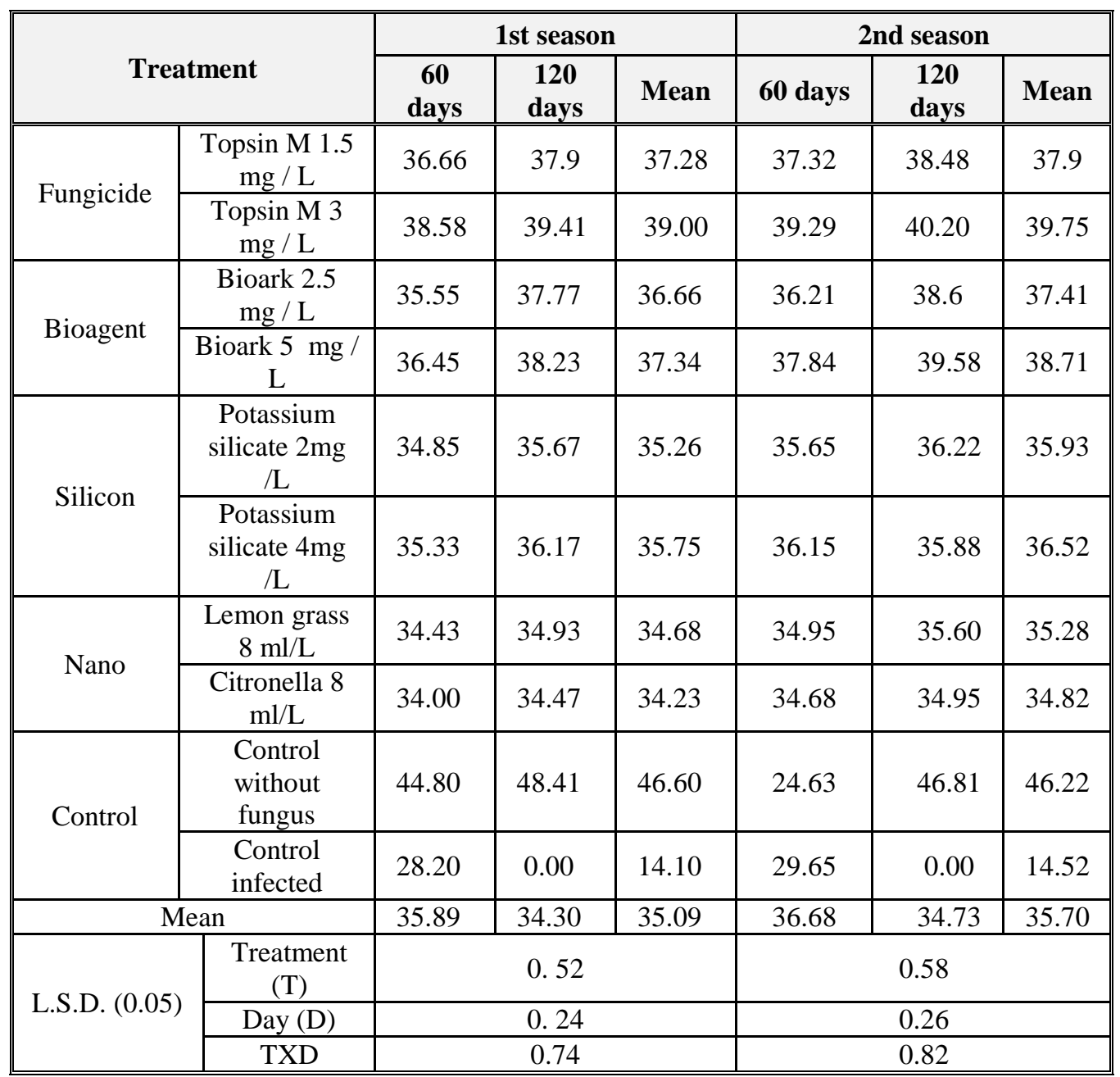

Effect of different treatments on branches fresh weight (gm): Table (4) showed that bioagent (Bioark $5 \mathrm{mg} / \mathrm{L}$ ) gave the highest effect in increasing of branches fresh weight in two seasons with mean value of $40.53 \mathrm{gm}$ and 41.32 gm for first and second seasons respectively compared to control infected 
with fungus 9.37 and $10.42 \mathrm{gm}$ for 1 st and 2 nd seasons respectively. The lowest significant effect of treatments was reported by using nano control Citronella $8 \mathrm{ml} / \mathrm{L}$ in the two seasons with 33.28 and $34.11 \mathrm{gm}$ for 1 st and $2 \mathrm{nd}$ seasons respectively compared to the control infected with fungus.

Table (4): Effect of treatments on branches fresh weight (gm) of Ocimum (sweet basil) infected with Fusarium through first and second seasons

\begin{tabular}{|c|c|c|c|c|c|c|c|}
\hline \multirow{2}{*}{\multicolumn{2}{|c|}{ Treatment }} & \multicolumn{3}{|c|}{ 1st season } & \multicolumn{3}{|c|}{ 2nd season } \\
\hline & & \multirow{2}{*}{$\begin{array}{c}\begin{array}{c}\mathbf{6 0} \\
\text { days }\end{array} \\
36.10\end{array}$} & \multirow{2}{*}{$\begin{array}{c}\begin{array}{c}120 \\
\text { days }\end{array} \\
34.46\end{array}$} & \multirow{2}{*}{$\begin{array}{l}\text { Mean } \\
35.28\end{array}$} & \multirow{2}{*}{$\begin{array}{c}60 \text { days } \\
36.58\end{array}$} & \multirow{2}{*}{$\begin{array}{c}\begin{array}{c}120 \\
\text { days }\end{array} \\
35.09\end{array}$} & \multirow{2}{*}{$\begin{array}{c}\text { Mean } \\
35.34\end{array}$} \\
\hline \multirow{2}{*}{ Fungicide } & $\begin{array}{c}\text { Topsin M } 1.5 \mathrm{mg} / \\
\mathrm{L}\end{array}$ & & & & & & \\
\hline & $\begin{array}{c}\text { Topsin M } 3 \text { mg / } \\
\text { L }\end{array}$ & 40.72 & 39.68 & 40.20 & 41.18 & 40.40 & 40.79 \\
\hline \multirow{2}{*}{ Bioagent } & Bioark $2.5 \mathrm{mg} / \mathrm{L}$ & 40.38 & 38.40 & 39.39 & 41.22 & 38.84 & 40.03 \\
\hline & Bioark $5 \mathrm{mg} / \mathrm{L}$ & 41.61 & 39.44 & 40.53 & 42.35 & 40.29 & 41.32 \\
\hline \multirow{2}{*}{ Silicon } & $\begin{array}{c}\text { Potassium silicate } \\
2 \mathrm{mg} / \mathrm{L}\end{array}$ & 35.03 & 34.48 & 34.76 & 35.65 & 36.21 & 35.43 \\
\hline & $\begin{array}{c}\text { Potassium silicate } \\
4 \mathrm{mg} / \mathrm{L}\end{array}$ & 37.90 & 36.68 & 37.29 & 38.31 & 37.46 & 37.89 \\
\hline \multirow[t]{2}{*}{ Nano } & $\begin{array}{c}\text { Lemon grass } 8 \\
\mathrm{ml} / \mathrm{L}\end{array}$ & 34.40 & 33.68 & 34.04 & 35.00 & 34.35 & 34.68 \\
\hline & Citronella $8 \mathrm{ml} / \mathrm{L}$ & 34.20 & 32.37 & 33.28 & 34.80 & 33.41 & 34.11 \\
\hline \multirow[t]{2}{*}{ Control } & $\begin{array}{c}\text { Control without } \\
\text { fungus }\end{array}$ & 45.20 & 47.58 & 46.39 & 47.04 & 47.35 & 47.20 \\
\hline & Control infected & 18.74 & 0.00 & 9.37 & 20.83 & 0.00 & 10.42 \\
\hline \multicolumn{2}{|r|}{ Mean } & 36.43 & 33.48 & 34.95 & 37.20 & 34.24 & 36.22 \\
\hline \multirow{3}{*}{ L.S.D. (0.05) } & \begin{tabular}{l|l} 
& Treatment $(\mathrm{T})$ \\
\end{tabular} & \multicolumn{3}{|c|}{1.20} & \multicolumn{3}{|c|}{4.21} \\
\hline & Day (D) & \multicolumn{3}{|c|}{0.54} & \multicolumn{3}{|c|}{1.88} \\
\hline & TXD & \multicolumn{3}{|c|}{1.70} & \multicolumn{3}{|c|}{5.95} \\
\hline
\end{tabular}

Effect of different treatments on branches dry weight (gm): Table (5)

showed that bioagent (Bioark $5 \mathrm{mg} / \mathrm{L}$ ) had the highest significant effect in increasing of dry weight of branches (gm) in two seasons and the increasing was found after 60 days than 120 days. Bioark $(5 \mathrm{mg} / \mathrm{L})$ effect in second 
J. Environ. Sci.

Institute of Environmental Studies and Research - Ain Shams University

season higher than first season with mean value $(13.2 \mathrm{gm})$ and $(12.65 \mathrm{gm})$ respectively. The lowest significant effect of treatment was observed by using nano Citronella $8 \mathrm{ml} / \mathrm{L}$ in the two seasons with mean values of $10.1 \mathrm{gm}$ and $10.72 \mathrm{gm}$ for $1 \mathrm{st}$ and $2 \mathrm{nd}$ seasons respectively compared to control infected with fungus 3.57 and 4.16 gm respectively.

Table (5): Effect of treatments on branches dry weight of Ocimum (sweet basil) infected with Fusarium through first and second seasons

\begin{tabular}{|c|c|c|c|c|c|c|c|}
\hline \multirow{2}{*}{\multicolumn{2}{|c|}{ Treatment }} & \multicolumn{3}{|c|}{ 1st season } & \multicolumn{3}{|c|}{ 2nd season } \\
\hline & & \multirow{2}{*}{$\begin{array}{c}\begin{array}{c}\mathbf{6 0} \\
\text { days }\end{array} \\
12.38\end{array}$} & \multirow{2}{*}{$\begin{array}{c}\begin{array}{c}120 \\
\text { days }\end{array} \\
12.55\end{array}$} & \multirow{2}{*}{$\frac{\text { Mean }}{11.96}$} & \multirow{2}{*}{$\begin{array}{c}60 \text { days } \\
12.69\end{array}$} & \multirow{2}{*}{$\begin{array}{c}\begin{array}{c}120 \\
\text { days }\end{array} \\
12.41\end{array}$} & \multirow{2}{*}{$\begin{array}{c}\text { Mean } \\
12.42\end{array}$} \\
\hline \multirow{2}{*}{ Fungicide } & $\begin{array}{l}\text { Topsin M } \\
1.5 \mathrm{mg} / \mathrm{L}\end{array}$ & & & & & & \\
\hline & $\begin{array}{c}\text { Topsin M } 3 \\
\text { mg / L }\end{array}$ & 12.88 & 11.83 & 12.36 & 13.18 & 12.43 & 12.81 \\
\hline \multirow{2}{*}{ Bioagent } & $\begin{array}{c}\text { Bioark 2.5 } \\
\mathrm{mg} / \mathrm{L}\end{array}$ & 11.77 & 11.37 & 11.57 & 12.14 & 11.66 & 11.90 \\
\hline & $\begin{array}{c}\text { Bioark } 5 \mathrm{mg} \\
/ \mathrm{L}\end{array}$ & 13.00 & 12.30 & 12.65 & 13.49 & 12.90 & 13.20 \\
\hline \multirow{2}{*}{ Silicon } & $\begin{array}{c}\text { Potassium } \\
\text { silicate } 2 \mathrm{mg} \\
/ \mathrm{L} \\
\end{array}$ & 11.86 & 11.28 & 11.57 & 12.10 & 11.63 & 11.89 \\
\hline & $\begin{array}{c}\text { Potassium } \\
\text { silicate } 4 \mathrm{mg} \\
/ \mathrm{L}\end{array}$ & 12.24 & 11.87 & 12.06 & 12.67 & 12.38 & 12.52 \\
\hline \multirow{2}{*}{ Nano } & $\begin{array}{c}\text { Lemon grass } \\
8 \mathrm{ml} / \mathrm{L}\end{array}$ & 10.79 & 10.40 & 10.59 & 11.02 & 10.25 & 10.88 \\
\hline & $\begin{array}{c}\text { Citronella } 8 \\
\mathrm{ml} / \mathrm{L}\end{array}$ & 10.21 & 9.99 & 10.1 & 10.82 & 10.62 & 10.72 \\
\hline \multirow[t]{2}{*}{ Control } & $\begin{array}{l}\text { Control } \\
\text { without } \\
\text { fungus } \\
\end{array}$ & 14.02 & 13.14 & 13.58 & 14.15 & 14.53 & 14.34 \\
\hline & \begin{tabular}{|c|} 
Control \\
infected \\
\end{tabular} & 7.15 & 0.00 & 3.57 & 8.32 & 0.00 & 4.16 \\
\hline \multicolumn{2}{|c|}{ Mean } & 11.63 & 10.37 & 11.00 & 12.06 & 10.91 & 11.48 \\
\hline \multirow{3}{*}{$\begin{array}{l}\text { L.S.D. } \\
(0.05)\end{array}$} & Treatment $(\mathrm{T})$ & \multicolumn{3}{|c|}{0.47} & \multicolumn{3}{|c|}{0.69} \\
\hline & Day (D) & \multicolumn{3}{|c|}{0.21} & \multicolumn{3}{|c|}{0.31} \\
\hline & TXD & \multicolumn{3}{|c|}{0.57} & \multicolumn{3}{|c|}{0.98} \\
\hline
\end{tabular}


Effect of different treatments on root length $(\mathrm{cm})$, fresh weight and dry weight (gm): Table (6), showed that the highest significant increase of treatments on the root length, root dry weight and root fresh weight was appeared by using bioagent treatment (Bioark $5 \mathrm{mg} / \mathrm{L}$ ) for two seasons. Bioark fertilizer showed higher increase in root parameters in 2nd season than 1 st season.

For root length, Bioark $(5 \mathrm{mg} / \mathrm{L})$ gave the highest increase 12.43 and $12.98 \mathrm{~cm}$ for $1 \mathrm{st}$ and $2 \mathrm{nd}$ respectively compared to the control infected with fungus 0.00 for root fresh and dry weights, Bioark $(5 \mathrm{gm} / \mathrm{L})$ gave the most significant increase in 2nd seasons 16.01 and 6.94 gm compared with control infected with fungus (0.00).

Nano control using Citronella $8 \mathrm{ml} / \mathrm{L}$ gave the lowest significant of treatments on root length, root fresh and dry weights in two seasons compared to the control. 
J. Environ. Sci.

Institute of Environmental Studies and Research - Ain Shams University

Table (6): Effect of treatments on root (length, fresh weight and dry weight) of Ocimum (sweet basil) infected with Fusarium through first and second seasons.

\begin{tabular}{|c|c|c|c|c|c|c|c|}
\hline \multirow{2}{*}{\multicolumn{2}{|c|}{ Treatment }} & \multicolumn{2}{|c|}{$\begin{array}{l}\text { Root length } \\
\text { (cm) }\end{array}$} & \multicolumn{2}{|c|}{$\begin{array}{l}\text { Root fresh } \\
\text { weight (mg) }\end{array}$} & \multicolumn{2}{|c|}{$\begin{array}{c}\text { Root Dry } \\
\text { weight } \\
\text { (mg) }\end{array}$} \\
\hline & & 1st & 2nd & 1st & 2nd & $1 \mathrm{st}$ & 2nd \\
\hline \multirow{2}{*}{ Fungicide } & $\begin{array}{c}\text { Topsin M } 1.5 \mathrm{mg} \\
/ \mathrm{L}\end{array}$ & 11.87 & 12.11 & 14.31 & 14.85 & 6.24 & 6.45 \\
\hline & $\begin{array}{c}\text { Topsin M } 3 \text { mg / } \\
\text { L }\end{array}$ & 12.31 & 12.46 & 15.03 & 15.47 & 6.5 & 6.98 \\
\hline \multirow[t]{2}{*}{ Bioagent } & $\begin{array}{c}\text { Bioark } 2.5 \mathrm{mg} / \\
\mathrm{L}\end{array}$ & 12.20 & 12.55 & 14.60 & 15.05 & 6.00 & 6.25 \\
\hline & Bioark $5 \mathrm{mg} / \mathrm{L}$ & 12.43 & 12.98 & 15.48 & 16.01 & 6.68 & 6.94 \\
\hline \multirow{2}{*}{ Silicon } & $\begin{array}{l}\text { Potassium silicate } \\
2 \mathrm{mg} / \mathrm{L}\end{array}$ & 11.42 & 11.72 & 13.29 & 12.25 & 5.72 & 6.00 \\
\hline & $\begin{array}{c}\text { Potassium silicate } \\
4 \mathrm{mg} / \mathrm{L}\end{array}$ & 11.78 & 12.05 & 13.69 & 13.82 & 5.77 & 5.96 \\
\hline \multirow[t]{2}{*}{ Nano } & $\begin{array}{c}\text { Lemon grass } 8 \\
\mathrm{ml} / \mathrm{L}\end{array}$ & 11.49 & 11.92 & 12.80 & 12.73 & 5.43 & 5.55 \\
\hline & Citronella $8 \mathrm{ml} / \mathrm{L}$ & 10.77 & 11.11 & 11.64 & 11.80 & 4.81 & 5.07 \\
\hline \multirow[t]{2}{*}{ Control } & $\begin{array}{l}\text { Control without } \\
\text { fungus }\end{array}$ & 14.49 & 13.84 & 17.63 & 16.00 & 6.49 & 7.26 \\
\hline & Control infected & 0.00 & 0.00 & 0.00 & 0.00 & 0.00 & 0.00 \\
\hline \multicolumn{2}{|c|}{ LSD 0.05} & 0.33 & 0.62 & 0.53 & 0.55 & 0.43 & 0.52 \\
\hline
\end{tabular}

Effect of different treatments on essential oil content of Ocimum

plant: Table (7) showed that the highest significant increase in essential oils content of Ocimum basilicum plant infected with Fusarium oxysporum was reported by using bioagent (Bioark $5 \mathrm{mg} / \mathrm{L}$ ), while the lowest significant effect was reported by using nano Citronella $8 \mathrm{ml} / \mathrm{L}$ in two seasons.

Bioark $5 \mathrm{gm} / \mathrm{L}$ and Topsin M $3 \mathrm{gm} / \mathrm{L}$ gave the highest effect in oil content with mean value $0.07 \mathrm{gm}$ compared to control infected with fungus $0.01 \mathrm{gm}$. 
The lowest effect was reported by using nano Citronella $8 \mathrm{ml} / \mathrm{L}$ in two seasons with mean value $0.03 \mathrm{gm}$ compared to the control infected with fungus.

Table (7): Effect of treatments on essential oil content of Ocimum (sweet basil) infected with Fusarium through first and second seasons.

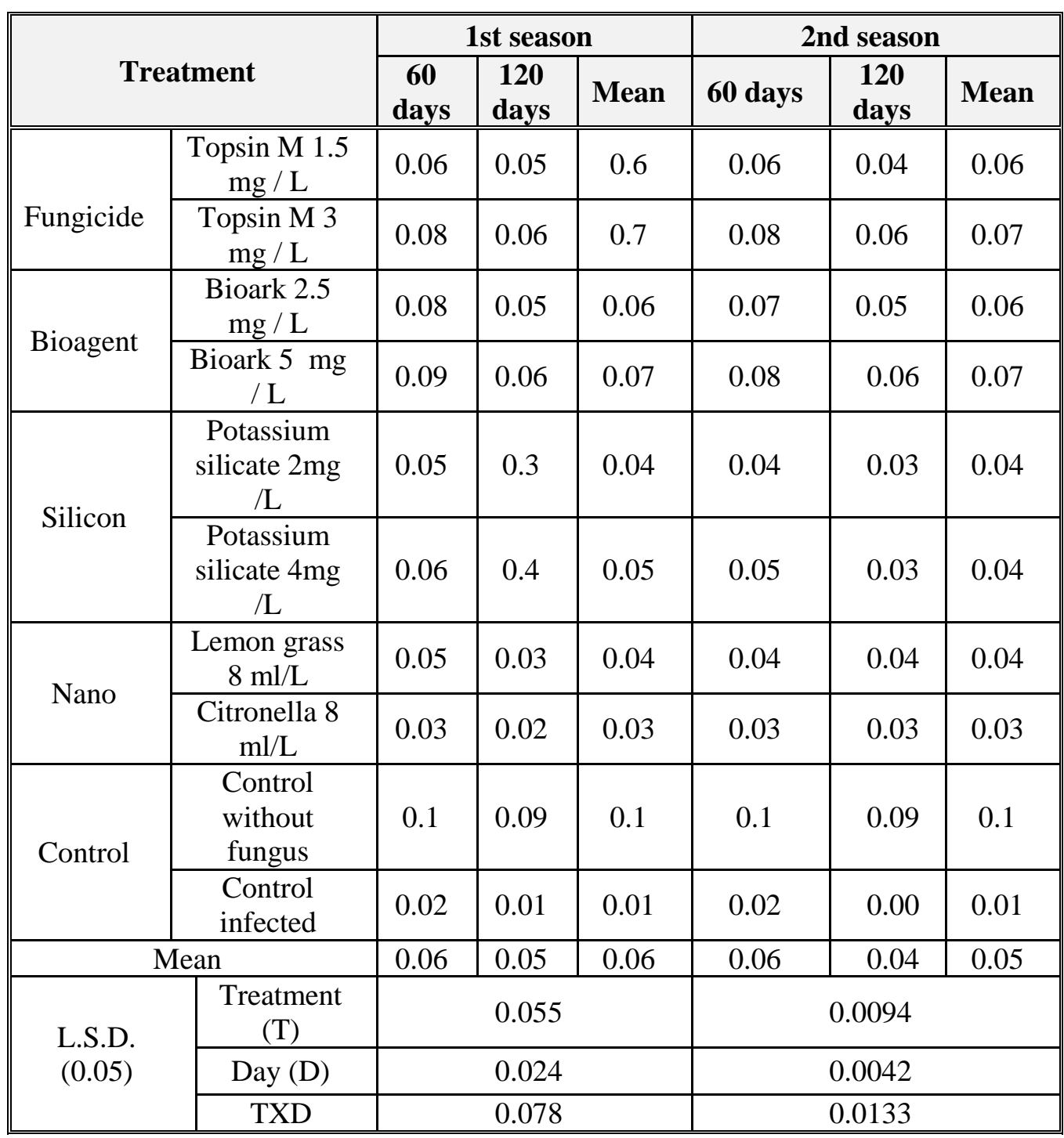


J. Environ. Sci.

Institute of Environmental Studies and Research - Ain Shams University

\section{DISCUSSION}

Sweet basil (Ocimum basilicum L.) is an economically important herb crop in several Mediterranean countries. Basil is also an important fresh and processed (frozen and pesto sauce) crop. The intensified use of cultivation systems, coupled with increasing restrictions on the use of fungicides, led to severe epidemics. The recent widespread outbreaks of Fusarium wilt (Davis et al., 1993).In this investigation the infection of basil with wilt disease was highest in Beni-Suif Governorate.

Topsin-M is fungicide widely available for commercial purpose amended at different concentrations in PDA inhibited growth of the fungus. Topsin M (Methyl thiophenate) is a systematic fungicide used for control of diseases such as powdery mildew and downy mildew of basil and other plants (Singh, 1991). Topsin M (3 mg/L) gave the highest efficiency in plant length increasing infected with Fusarium in 1st and 2nd seasons, this result was in agreement with result of Hilal et al. (2008). This may due to the direct effect of Topsin $\mathrm{M}$ on the fungal growth, reducing or preventing the fungal pathogenicity and changing the soil microflora profile; the fungicides were recommended to control wilt disease of many hosts (Hilal et al., 2003).

Natural safety bioagent causes various promotion effects on plants. It is considered as a natural source of cytokinins which stimulates cell division and enlargement as well as the synthesis of protein, nucleic acid and Bvitamin. It also releases $\mathrm{CO}_{2}$ which reflected in improving net photosynthesis. Bioagents are applied as seed or soil inoculants, they multiply and participate in nutrient cycling and benefit crop productivity (Singh et al., 2011). In general, $60 \%$ to $90 \%$ of the total applied fertilizer is lost and the remaining 
$10 \%$ to $40 \%$ is taken up by plants. In this regard, microbial inoculants have paramount significance in integrated nutrient management systems to sustain agricultural productivity and healthy environment (Adesemoye and Kloepper, 2009).

The significant effect of bioagent may be due to the effect of different strain groups and nutrients mobilizing microorganisms which help in availability of metals and their forms in the composted material and increased levels of extracted minerals (El-Kramany et al., 2000).Using bioagents produce antifungal antibiotics and growth substances that improved seed germination and plant stand (Shende et al., 1977) and plant growth regulators (Reddy et al., 1991).In this study bioagent (Bioark $5 \mathrm{mg} / \mathrm{L}$ ) gave the highest significant increase in branches fresh and dry weights; in addition to increasing in root length and root fresh and dry weights. Also, Bioark gave the highest significant increasing in oil content of Basil infected with Fusarium oxysporum. Bioagents promote growth by increasing the supply or availability of primary nutrients to the host plant (Lakshmi Kumari et al., 1975)

The addition of a specific biological control agent to compost was reported leading to a substrate with a broader-range suppressive effect (Qiu et al., 2012; Pugliese et al., 2011; Shoda, 2000), and such substrate has been widely used to control soil borne diseases, especially Fusarium wilt disease (Alabouvette et al., 2006). In conclusion, bioagent (Bioark $5 \mathrm{mg} / \mathrm{L}$ ) was the most effective control in increasing the branches fresh and dry weights; root length, root fresh and dry weights; in addition to oil content of infected basil with Fusarium oxysporum. 
J. Environ. Sci.

Institute of Environmental Studies and Research - Ain Shams University

\section{REFERENCES}

Adesemoye, A.O. and Kloepper, J. W. (2009): Plant-microbes interactions in enhanced fertilizer-use efficiency. Appl Microbiol Biotechnol, $85: 1-12$.

Alabouvette, C.; Olivain, C. and Steinberg, C. (2006): Biological control of plant diseases: the European situation. Eur. J. Plant Pathol. 114, 329-341.

Al-Hatmi, A. M. S.; Bonifaz, A.; De Hoog, G. S.; Vazquez-Maya, L.; GarciaCarmona, K. and Meis, J. F. (2014): Keratitis by Fusarium temperatum, a novel opportunist. BMC Infect. Dis. 14:588.

Booth, C. (1985): The genus Fusarium. Commonwealth Mycological Institute, Kew. Surrey, England, 237 pp.

Burrges, L. W.; C. M. Liddell and B. A. Summerell (1988): Laboratory manual for Fusarium research. Incorporating a Key and descriptions of common species found in Australia (second edition). Fusarium research Laboratory Department of Plant Pathology and Agricultural Entomology the University of Sydney, $156 \mathrm{pp}$.

Davis, R. M.; Marshall, K. D. and Valencia, J. (1993): First report of Fusarium wilt of basil in California. Plant Dis. 77:537.

Ellis, M. B. (1971): Dematiaceous Hyphomycetes. CMI, Kew, Surrey, England, $608 \mathrm{pp}$.

El-Karmany, M.F.; Ahmed, M.K.; Bahr, A.A. and Kabesh, M.O. (2000): Utilization of bio-fertilizers in field crop production. Egypt J. Appl. Sci., 15(11): 137.

Gilardi, G.; Demarchi, S.; Garibaldi, A. and Gullino, M. L. (2012): Management of downy mildew of sweet basil (Ocimum basilicum) caused by Peronospora belbahrii by means of resistance inducers, fungicides, biocontrol agents and natural products. Phytoparasitica. 41:59-72.

Guenther, E. (1961): "The Essential oils" D- van Nostrond comp. Inc. New York, Vol. 1, 3 and 4.

Hilal, A.; Abd El-Rahman, T.; Ismail, I. M. and Ghebrial, E. W. (2008): Fusarium wilt (F. oxysporum f. sp. basilica) of sweet Basil in Egypt: II. The disease control. Egypt. J. Appl. Sci.: 1-27. 
Hilal, A.A.; Zaky, W. H.; Nada, M.G.A. (2003): New strategies for the management of some soilborne fungal diseases of the ornamental plants; croton and bulbous iris. Egypt. J. Appl. Sci., 18(12):64-90.

Homa, K.; Barney, W. P.; Ward, D. L.; Wyenandt, C. A. and Simon, J. E. (2014). Evaluation of fungicides for the control of Peronospora belbahrii on sweet basil in New Jersey. Plant Dis.98:1561-1566.

Javanmardi, J.; Khalighi, A.; Kashi, A.; Bais, H.P. and Vivanco, J.M. (2002): Chemical characterization of basil (Ocimum basilicum L.) found in local accessions and used in traditional medicines in Iran. J. Agric. Food Chem., 50(21): 5878-5883.

Lakshmi Kumari, M.; Vijayakshmi, K. and Subba Rao, N.S. (1975): Interaction between Azobacter sp. and fungi. I. In vitro studies with Fusarium moniliforme Sheld. Phytopathol. Z., 75:27-30.

Lamb, C. and R.A. Dixon, (1997): The oxidative burst in plant disease resistance. Annu Rev Plant Biol., 48: 251-275.

Lee, J. and Scagel, C.F. (2009). Chicoric acid found in basil (Ocimum basilicum L.) leaves. Food Chem., 115(2): 650-656.

Mabey, R.; Mclntyre, M.; Michael, P.; Duff, G. and Stevens, J. (1988):.“The New Age Herbalist". Collier Books Macmillan Publishing Company New York. pp.55-56.

Moubasher, A. H.; I. A. El-Kady and S. M. Farghally (1977): The mycoflora of some Egyptian seeds and their potentialities for production of aflatoxins. Zeszyty Problemowe Postepow Nauk Rolniczych, 189: 141-147.

Nelson, P.E.; Toussoun, T.A. and Marasas, W.F.O. (1983): Fusarium species: An Illustrated manual for identification. University Park: Pennsylvania State University Press; p. 193.

Pugliese, M.; Liu, B.; Gullino, M.L. and Garibaldi, A. (2011): Microbial enrichment of compost with biological control agents to enhance suppressiveness to four soil-borne diseases in greenhouse. J. Plant Dis. Protect 118:45-50.

Qiu, M.; Zhang, R.; Xue, C.; Zhang, S.; Li, S.; Zhang, N.and Shen, Q. (2012): Application of bio-organic fertilizer can control Fusarium wilt of cucumber plants by regulating microbial community of rhizosphere soil. Biol. Fert. Soils 48: 807-816. 
Reedy, M. S.; Cambpell, S.E.; Young, S. E. and Brown, G. (1991):.Greenhouse evaluation of rhizobacteria for the suppression of crown and root-rot of tomato caused by Fusarium oxysporum f.sp. lycopersici. Bull.-SROP, 14(8):39-44.

Sakr, S.A. and AL-Amoudi, W.M. (2012). Effect of leave extract of Ocimum basilicum on deltamethrin induced nephrotoxicity and oxidative stress in albino rats. J. Appl. Pharm. Sci., 2(5):22-27.

Shende, S. T.; Apte, R. G. and Singh, T. (1977): Influence of Azotobacter on germination of rice and cotton seeds. Curr.Sci., 46:675.

Shiga, T.; Shoji, K.; Shimada, H.; Hashida, S. N.; Goto, F. and Yoshihara, T. (2009): Effect of light quality on rosmarinic acid content and antioxidant activity of sweet basil, Ocimum basilicum L. Plant Biotechnol., 26(2):255-259.

Shoda, M. (2000): Bacterial control of plant diseases. J. Biosci. Bioeng. 89:515-521.

Singh, J.S.; Pandey, V.C. and Singh, D.P. (2011): Efficient soil microorganisms: a new dimension for sustainable agriculture and environmental development. Agric Ecosyst Environ, 140:339353.

Singh, K.; J. C. Frisvad; U. Thrance and S. B. Mathur (1991): An illustrated manual on identification of some seed-borne Aspergilli, Fusaria, Penicillia and their Mycotoxins. Danich Government Institute of Seed Pathology for developing countries, Hellerup, Copenhagen, Denmark.

Singh, R. (1991): Management of disease with chemical. In: Introduction to principle of plant pathology. 3rd edition. Oxford \& IBH Pub. New Dehli. India.

Snedecor, G. W. and Cochran, W. G. (1989): Statistical Methods. 8th Edn., Iowa State University Press, Iowa, USA.

Wang, B.; Yuan, J.; Zhang, J.; Shen, Z.; Zhang, M.; Li, R.; Ruan, Y. and Shen, Q. (2013): Effects of novel bioorganic fertilizer produced by Bacillus amyloliquefaciens W19 on antagonism of Fusarium wilt of banana. Biol. Fert. Soils, 49:435-446. 
Zhao, S.; Liu, D.; Ning, L.; Chen, F.; Fang, W. and Shen, Q. (2014): Bioorganic fertilizer application significantly reduces the Fusarium oxysporum population and alters the composition of fungi communities of watermelon Fusarium wilt rhizosphere soil. Biol. Fert. Soils, 50: 765-774.

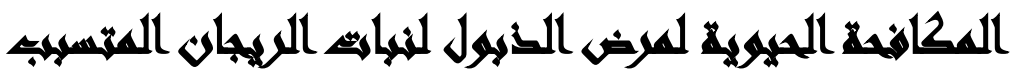

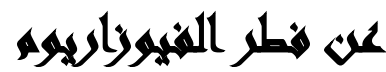

[

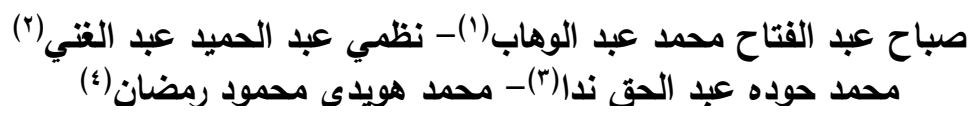

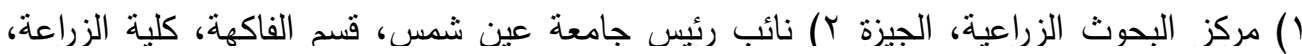

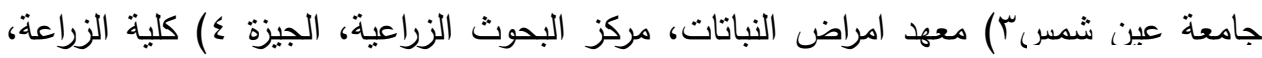

\section{المستخلص}

تهذف هذه الدراسة الى دراسة نبات الريحان المصاب بفطر الفيوزاريوم اوكسيسبورم في ثلاث

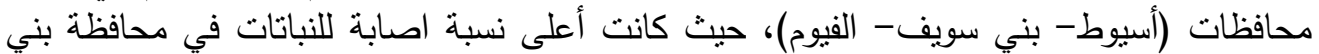

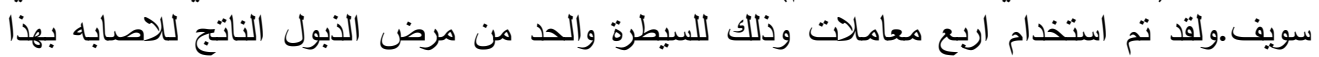

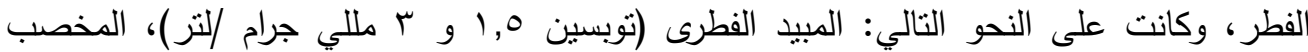

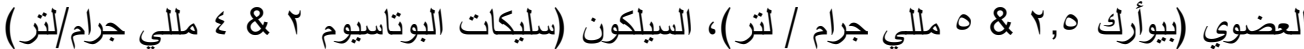

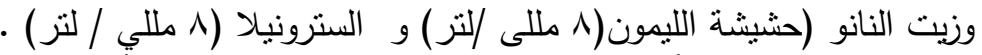

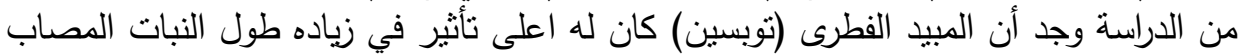

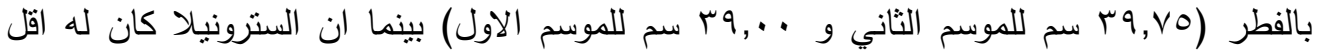

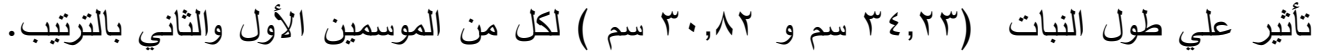

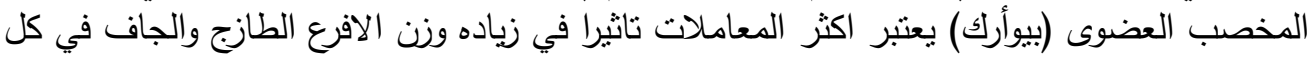

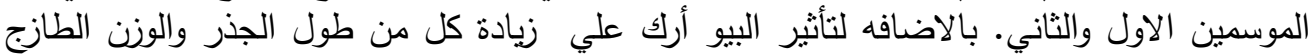

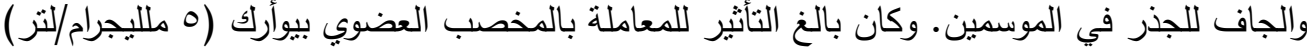

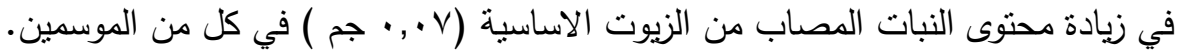

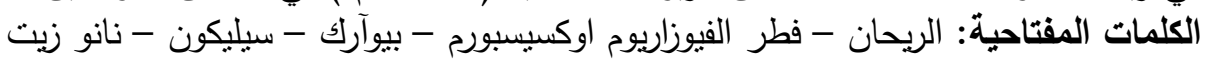

